\title{
NOTES ON FOOD HABITS OF SMALL MAMMALS OF THE WHITE SPRUCE FOREST ${ }^{1}$
}

\author{
By J. W. BRUCE WAGG ${ }^{2}$
}

\section{ABSTRACT}

Cage feeding of deer mice, Peromyscus maniculatus, and red-backed mice, Clethrionomys gapperi, showed a daily maximum seed consumption of lodgepole pine, Pinus contorta var. latifolia, of about 1,000 seeds and of white spruce, Picea glauca, of 2,000 seeds. There was no difference in the amount of seed consumed by the two species of mice. Lodgepole pine seed was preferred over white spruce.

Meadow voles, Microtus spp., readily ate lodgepole pine and white spruce seedlings following germination. Red-backed mice also ate seedlings but not to the same degree as the meadow voles. The deer mouse was not tested.

\section{CONCLUSIONS ET RESUME}

La souris à dos roux est un petit rongeur commun qui forme parfois une forte proportion de la population de petits mammifères des forêts d'épinette blanche. Des expériences d'alimentation de souris à dos roux et de souris à pattes blanches en cage ont révélé que ces rongeurs consommaient quotidiennement au plus I,000 graines de pin de Murray et 2,000 graines d'épinette blanche. Nous n'avons constaté aucune différence marquée de la consommation de graines entre ces deux espèces, bien que la souris à dos roux ait semblé moins satisfaite que la souris à pattes blanches d'un régime formé uniquement de graines. Les deux espèces de souris préféraient les graines de pin de Murray à celles d'épinette blanche.

Les campagnols des champs et les campagnols à queue longue consommaient volontiers aussi bien des cotylédons de pin de Murray que ceux diépinette blanche au cours de leur première saison de croissance. Les souris à dos roux mangeaient aussi de ces plantules, mais pas autant que les campagnols. Cette expérience n'a pas été faite avec des souris à pattes blanches.

Du fait que ces petits mammifères ont été soumis aux expériences dans des conditions artificielles, on ne peut présumer que les résultats obtenus correspondent à leur consommation de graines en forêt. Dans la nature, la survivance des graines d'arbres aux ravages des petits mammifères dépend de facteurs tels que la densité et l'activité des mammifères, la densité des graines, la diversité d'autres matières nutritives et nombre d'autres. Ce n'est que par une vaste étude d'ensemble qu'on pourra préciser suffisamment linfluence des petits mammifères sur la régénération dans les forêts d'épinette blanche.

\footnotetext{
${ }^{1}$ Contribution No. 517, Forest Research Branch, Department of Forestry, Ottawa, Canada. ${ }^{2}$ Research Officer, Forest Research Branch, Department of Forestry, Calgary, Alberta.
} 


\section{INTRODUCTION}

During studies of white spruce regeneration in Wood Buffalo National Park in 1959 it was noticed that deer mice and red-backed mice were abundant on clear-cut areas. Similar populations were found at Hinton, Alberta, the following season.

Deer mice and chipmunks are known to be detrimental to forest regeneration, but the role of red-backed mice is not as well known (Smith and Aldous 1947). Deer mice appear to prefer tree seed for food; whereas red-backed mice and chipmunks feed on seeds and succulent vegetation (Bailey 1936, Smith and Aldous 1947).

During the summer of 1960 cage-feeding studies were conducted at Hinton, Alberta with deer mice and red-backed mice to establish the maximum sustained consumption of lodgepole pine and white spruce seed, the relative seed consumption by the two species of mice, and their preference for the two species of tree seed. Other observations were made on feeding habits of the mice in the field and on other small mammals.

\section{Cage Feedings of Seed}

In the feeding tests the animals were placed in cylindrical cages, which were 18 inches high and 9 inches in diameter, and constructed of hardware cloth with the floor of the same material situated two inches above the base of the cylinder. A pan was placed on the top as a cover and one was placed underneath the cage to catch the seed and hulls that dropped through the floor.

The animals had access to water at all times but were provided only seed for food. From cutting tests the white spruce seed was 97 per cent sound and the lodgepole pine 99 per cent.

\section{Maximum Seed Consumption}

In tests for daily maximum seed consumption the animals, after capture in live traps, were placed directly into the feeding cages.

TABLE 1

Daily Consumption of 2,000 White Spruce Seed

\begin{tabular}{|c|c|c|c|c|c|c|c|c|c|c|c|}
\hline \multirow{4}{*}{$\begin{array}{l}\text { Species } \\
\text { Deer } \\
\text { mouse }\end{array}$} & \multirow{3}{*}{$\begin{array}{c}\begin{array}{c}\text { Animal } \\
\text { No. }\end{array} \\
9\end{array}$} & \multicolumn{3}{|c|}{ Ist Day } & \multicolumn{3}{|c|}{ 2nd Day } & \multicolumn{3}{|c|}{ 3rd Day } & \multirow{2}{*}{$\frac{\text { Mean }}{\text { Ate }}$} \\
\hline & & \multirow{2}{*}{$\begin{array}{c}\text { Ate } \\
1660\end{array}$} & \multicolumn{2}{|c|}{ Lost Remain } & \multirow{2}{*}{$\begin{array}{c}\text { Ate } \\
1928\end{array}$} & \multicolumn{2}{|c|}{ Lost Remain } & \multirow{2}{*}{$\frac{\text { Ate }}{1930}$} & \multirow{2}{*}{$\frac{\text { Lost }}{65}$} & \multirow{2}{*}{$\frac{\text { Remain }}{5}$} & \\
\hline & & & 323 & $1^{\prime}$ & & 67 & 5 & & & & 1839 \\
\hline & 11 & 1804 & 182 & 12 & 1812 & 187 & 1 & 1713 & 146 & 141 & 1776 \\
\hline & 8 & 1846 & 141 & 13 & 000 & 132 & 0 & 1992 & 8 & 0 & 1902 \\
\hline & mean & 1770 & - & - & 1869 & - & - & 1878 & - & - & 1839 \\
\hline Red- & 19 & 1667 & 333 & 0 & 1919 & 81 & 0 & 196 & 40 & 0 & 1849 \\
\hline & 22 & 1762 & 235 & 3 & 1796 & 203 & 1 & 1875 & 3 & 122 & 1811 \\
\hline mouse & 23 & 1810 & 180 & 10 & 1834 & 164 & 2 & 1749 & 250 & 1 & 1798 \\
\hline & mean & 1746 & - & - & 1850 & - & - & 1861 & - & $\longrightarrow$ & 1819 \\
\hline $\mathrm{za}$ & 16 & 1542 & 458 & 0 & 1698 & 302 & 0 & 1922 & 78 & 0 & 1721 \\
\hline & $\times 24$ & 1587 & 323 & 90 & 1743 & 257 & 0 & 1831 & 168 & 1 & 1720 \\
\hline & mean & 1564 & - & - & 1720 & $\longrightarrow$ & - & 1876 & & & 1720 \\
\hline
\end{tabular}


The average seed consumption per day was: deer mouse, 1839; redbacked mouse, 1819; and least chipmunk, Eutamias minimus (Bachman), 1720.

The seeds tabulated as lost fell into the pan below the floor of the cage and were not available to the animal: the other remaining seeds were either in the feeding dish or in the bedding provided for the animal.

In a further study, three deer mice, three red-backed mice and one least chipmunk were fed at the rate of 1,000 lodgepole pine seeds a day for three consecutive days. The daily rate of consumption is presented in Table 2.

TABLE 2

Daily Consumption of 1,000 Lodgepole Pine Seed

\begin{tabular}{|c|c|c|c|c|c|c|c|c|c|c|c|}
\hline \multirow{2}{*}{ Species } & \multirow{2}{*}{$\begin{array}{l}\text { Animal } \\
\text { No. } \\
\end{array}$} & \multicolumn{3}{|c|}{ 1st Day } & \multicolumn{3}{|c|}{ 2nd Day } & \multicolumn{3}{|c|}{ 3rd Day } & \multirow{2}{*}{$\begin{array}{l}\text { Mean } \\
\text { Ate }\end{array}$} \\
\hline & & Ate & Lost & Remain & $\overline{\text { Ate }}$ & Lost & Remain & $\overline{\text { Ate }}$ & Lost & Remain & \\
\hline Deer & 1 & 999 & 1 & 0 & 997 & 1 & 2 & 1000 & 0 & 0 & 999 \\
\hline \multirow[t]{3}{*}{ mouse } & 4 & 994 & 4 & 2 & 986 & 13 & 1 & 999 & 1 & 0 & 993 \\
\hline & 21 & 992 & 7 & 1 & 995 & 4 & 1 & 997 & 2 & 1 & 995 \\
\hline & mean & 995 & - & - & 993 & - & - & 999 & - & - & 995 \\
\hline Red- & 5 & 899 & 27 & 74 & 405 & 496 & 99 & 890 & 79 & 31 & $\overline{731}$ \\
\hline backed & 10 & 904 & 96 & 0 & 802 & 198 & 0 & 856 & 144 & 0 & 854 \\
\hline \multirow[t]{2}{*}{ mouse } & 12 & 690 & 310 & 0 & 887 & 52 & 61 & 885 & 91 & 24 & 821 \\
\hline & mean & 831 & - & - & 698 & - & - & 877 & & & 802 \\
\hline $\begin{array}{l}\text { Least } \\
\text { chip'unk }\end{array}$ & 3 & 981 & 19 & 0 & 1,000 & 0 & 0 & 891 & 102 & 7 & 957 \\
\hline
\end{tabular}

The average seed consumption for the three-day period was the deer mouse, 995; the red-backed mouse, 802; and the least chipmunk, 957. One other deer mouse which was fed 1,500 lodgepole pine seeds a day had an average daily consumption of 1168 seeds.

It is difficult to state from the feeding tests whether the deer mouse will eat more seed than will the red-backed mouse because the preponderance of the uneaten seed was scattered from the feeding dishes and fell through the floor of the cage. The red-backed mouse wasted more lodgepole pine seed than the deer mouse, perhaps indicating it was less satisfied with a pure seed diet. Both species lost more white spruce seed than lodgepole pine seed.

The 1,000 seeds of lodgepole pine per day and 2,000 seeds of white spruce appear to be near the maximum limit of daily consumption by the two species. In cage tests Willis (1914) found that deer mice ate 300 Douglas fir, Pseudotsuga menziesii (Mirb.) Franco, seeds daily. Abbott (1961) found that the average daily consumption was 109 eastern white pine, Pinus strobus L., seeds for Peromyscus leucopus (Raf.) and 97 seeds for the red-backed mouse.

The least chipmunks, being larger than mice and extremely active in the small cages, lost considerable seed through the floor of the cages. Consumption was similar to that of mice, but due to the inadequate size of cages, the tests were discontinued after feeding the first animals. 


\section{Seed Preference}

To evaluate seed preferences, three mice of each species were fed a mixture, of 1,000 white spruce and 1,000 lodgepole pine seeds and given two days to eat the mixture. The mice of each species were selected as follows: one from the previous feedings of lodgepole pine, one from the feedings of white spruce seed and one directly from a live trap in the field. Seed consumption rates are presented in Table 3 for the deer mice and the redbacked mice.

Both species showed a preference for lodgepole pine seed although, during the first day, feeding was not restricted to lodgepole pine. Horn (1939) found that mice and chipmunks preferred seed from large-seeded species over seed from small-seeded species, but that size was not the determining factor because the same order of preference prevailed when the seeds were made into a paste.

The first day's consumption of the combined seed was higher than in the previous cage feedings of lodgepole pine seed, being 1064 for the deer mice in contrast to 995 seeds; and 1,345 for red-backed mice as opposed to 802 seeds per day. This would further substantiate the conclusion that 1,000 lodgepole pine seeds are near the maximum daily consumption for these mice.

\section{Notes On A Cinereus Shrew and Red Squirrel}

One cinereus shrew, Sorex cinereus (Kerr), kept alive on immature ants and other insects, would accept lodgepole pine seed when the insect food was depleted. The shrew died after being fed for one day 200 seeds of lodgepole pine but did not die before 127 seeds were chipped into and some of the kernels partially eaten. When the seed was broken in two, the seed coat showed irregular serrations on the margin, and the kernel of the seed eaten. In other cases only a small fragment of the seed coat was removed leaving the exposed kernel intact. The importance of shrews in forest regeneration has already been discussed by Moore (1940), Kangur (1954) and others.

A mature red squirrel, Tamiasciurtts hudsomicus (Erxleben), was fed 50 staminate cones of white spruce in various stages of development in addition to the regular diet of seed, oatmeal and vegetables for three days. Although younger staminate cones were preferred, the squirrel ate all cones up to the pollen shedding stage. On the fourth day it was fed 500 staminate cones only, and ate 350 which corresponds with the figures given for Sciurus vulgaris $\mathbf{L}$. by Novikov (1953). The animal became sick and later died.

At Hinton, Alberta, red squirrels were observed cutting the lateral and terminal twigs and feeding on the vegetative and flower buds of white spruce (cf. e.g. Balch 1942, Lundberg 1946, Metzger 1946, Rowe 1952 and Adams 1955).

\section{Mouse Damage to Seedlings}

An enclosure was used to observe the feeding habits of red-backed mice and meadow voles and to determine if these species would damage white spruce and lodgepole pine seedlings. The enclosure 8 feet by 16 feet, placed in a cut-over area, was partly on an undisturbed habitat and partly on previously prepared seedbeds. Screens covered the seedbeds to prevent damage to the seedlings until the appropriate time. 


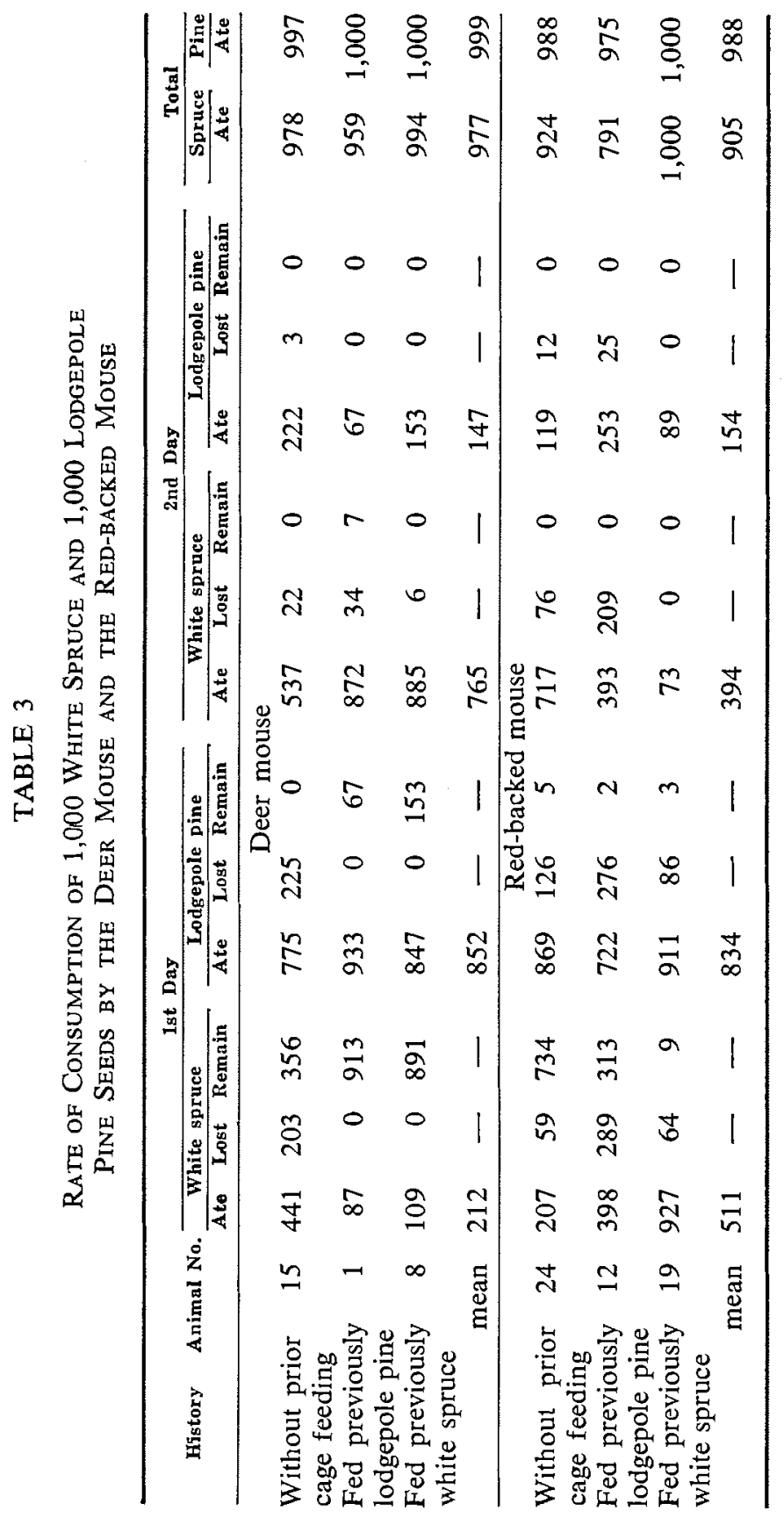






FIGURE 1. Sheet metal and hardware cloth enclosure.

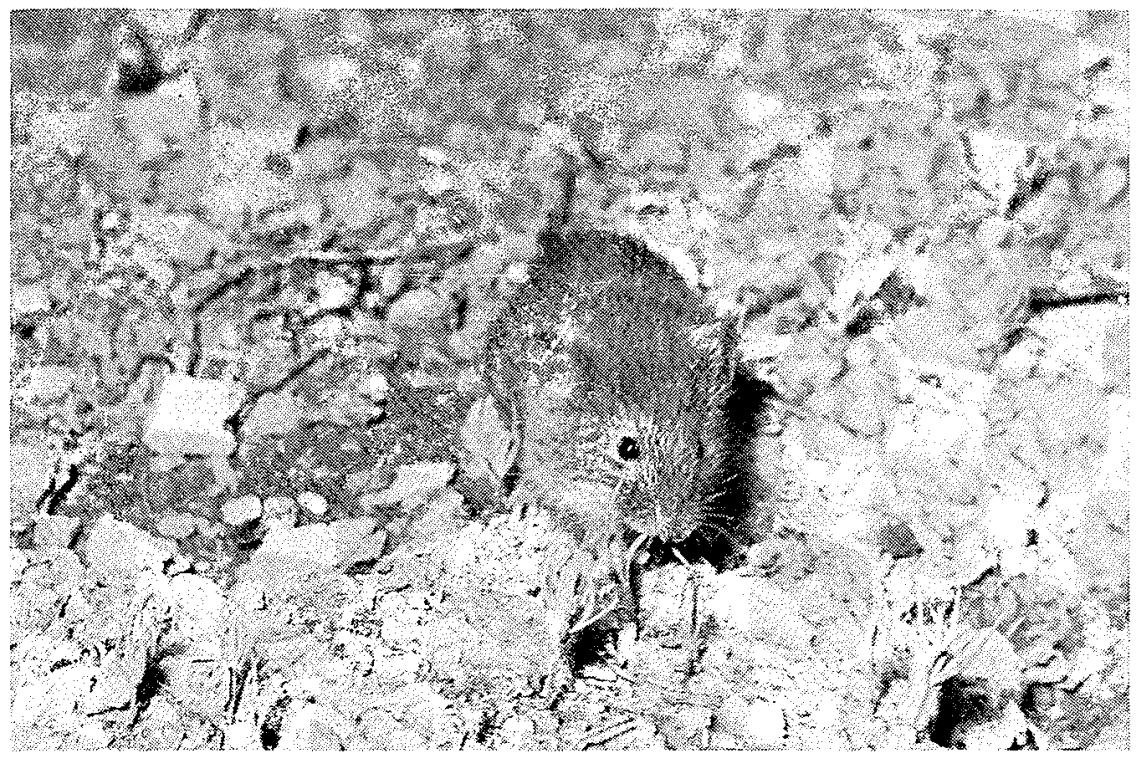

FIGURE 2. The red-backed mouse chewing on the cotyledons of lodgepole pine seedlings. 


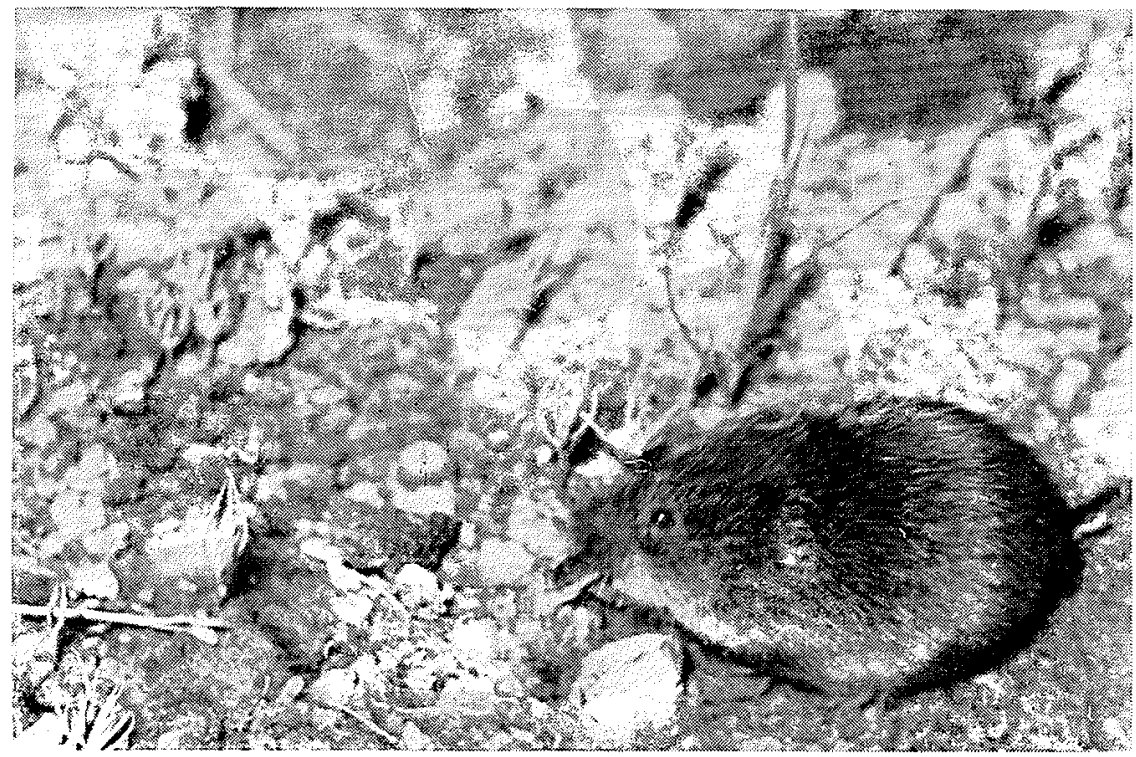

FIGURE 3. A short-tailed mendow vole eating a lodgepole pine secdling.

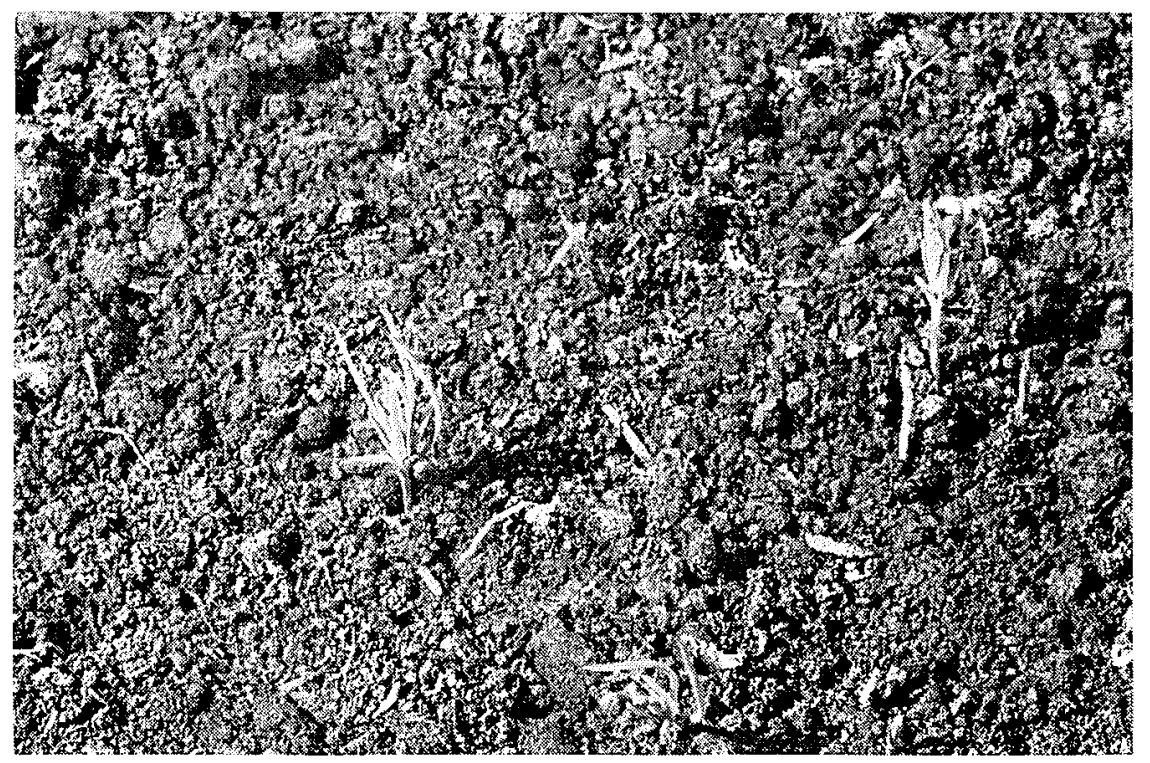

FIGURE 4. Damage to lodgepole pine seedlings by the long-tailed neadow vole. 
An inside corner of the enclosure is shown in Figure 1. The 18-inch wide hardware cloth, which formed the lower sidewall, was set 4 inches in the ground with another 4 inches bent at a right angle toward the center of the enclosure. A strip of sheet metal 12 inches wide was fastened to the top of the hardware cloth. The frame-work consisted of wooden posts placed on the outside of each corner and wood strips along each side which joined the hardware cloth and sheet metal.

After most of the seed coats had fallen from the seedlings, two mice of the same species were introduced into the enclosures. These were left for two days and fed, in addition to the food they could forage, oatmeal, vegetables and water. At the end of two days, the screens were removed from the seedlings. After the first pair of mice had been observed two others of the same or different species were introduced.

Although the red-backed mice ate some white spruce and lodgepole pine germinants they showed a preference for Equisetum scirpoides Michx. where it was associated with the seedlings. As in Figure 2, the red-backed mouse ate downward from the tips of the cotyledons.

The short-tailed meadow vole, Microtus pennsylvanicus (Ord), voraciously ate all lodgepole pine and white spruce seedlings available. These animals pulled the seedlings from the ground, held them between their front feet (Figure 3), and consumed the entire seedlings. Each group of seedlings was eaten completely in a rapid and systematic manner.

The only specimen of long-tailed meadow vole, Microtus longicaudus (Merriam), observed, either nipped the seedling off near the ground or chewed the cotyledons like the red-backed mouse. Figure 4 shows some damaged lodgepole pine seedlings.

Neither the long-tailed nor short-tailed meadow voles ate or damaged older seedlings during August in the enclosure at Hinton. These mice had access to other food, and the bark of the older seedlings may have been undesirable to them at this season. Cogshall (1928) mentions that deer mice will sometimes eat the bark and buds of Scots pine, Pinus sylvestris L.; and it might be assumed that meadow voles will eat the bark and buds of white spruce and lodgepole pine.

The damage to white spruce shown in Figure 5, may be ascribed to meadow voles in lieu of more complete knowledge. This type of damage was noted on groups of seedlings in favorable meadow vole habitats, and appeared to be the result of either biting or stripping the bark in the winter or early spring. The damage occurred over several seasons. 


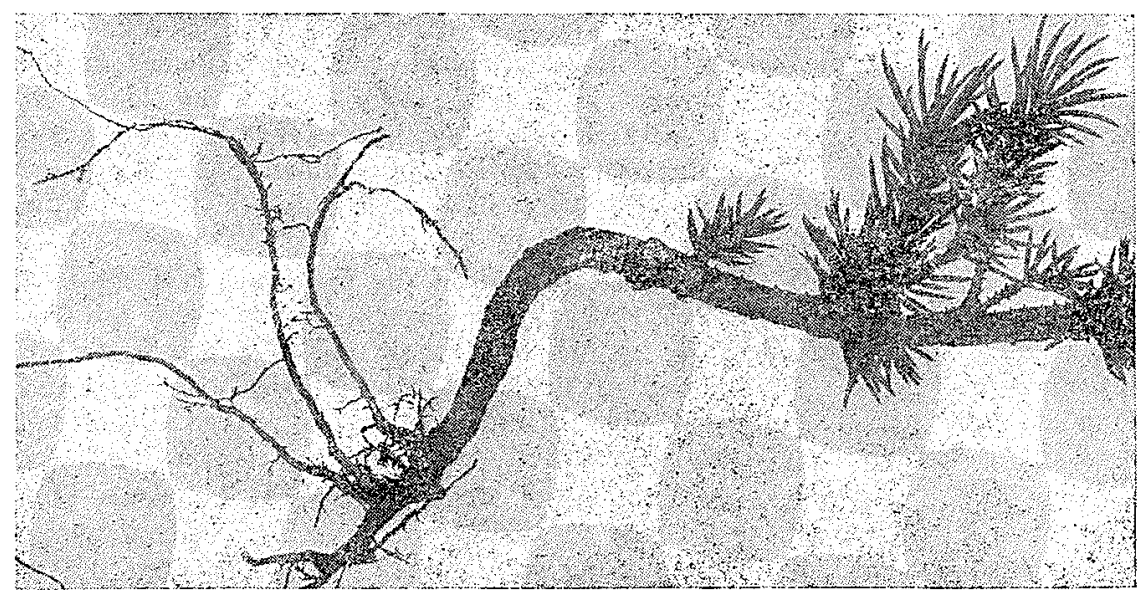

FIGURE 5. Damage to the bark and cambium of small white spruce at ground level.

\section{CONCLUSIONS AND SUMMARY}

The red-backed mouse is a common and sometimes abundant member of the small mammal population in the white spruce forest. Cage-feeding studies with the red-backed mouse and the deer mouse showed the daily maximum consumption of lodgepole pine to be about 1,000 seeds and of white spruce 2,000 seeds. There was not an obvious difference in the consumption rates although the red-backed mouse appeared less satisfied with a pure seed diet than the deer mouse. Both species of mice preferred lodgepole pine seed to white spruce.

The short-tailed and long-tailed meadow voles readily ate both lodgepole pine and white spruce seedlings during the first growing season. The redbacked mouse also ate young seedlings but not to the same degree as the meadow voles. The deer mouse was not tested.

Since the small mammals were studied under artificial conditions, it is not possible to interpret the results in terms of seed consumption in the field. Under natural conditions the survival of tree seed from small mammal depredation is dependent upon such factors as: mammal density, mammal activity, seed density, variety of alternative foods and many others. It would only be after a comprehensive study that the role of small mammals in white spruce regeneration silviculture can be adequately stated. 


\section{Literature Cited}

ABBOTT, H. G. 1961. White pine seed consumption by small mammals. Journal Forestry 59(3): $197-201$.

ADAMS, L. 1955. Pine squirrels reduce future crops of ponderosa pine cones. Journal Forestry $53(1): 35$.

BAILEY, V. 1936. The mammals and life zones of Oregon. U.S. Dept. Agriculture, Bureau of Biological Survey, North American Fauna 55:416 pp.

BALCH, R. E. 1942. A note on squirrel damage to conifers. Forestry Chronicle 18(1): 42.

COGSHALL, A. S. 1928. Food habits of deer mice of the genus Peromyscus in captivity. Journal Mammalogy $9(3): 217-221$.

HALL, E. R. and K. R. KELSON. 1959. The Memmals of North America. The Ronald Press Company, New York. Vol. I, XXX +1-546 pp. Vol. II, VIII +547-1083 pp. 79 pp. index in each volume.

HORN, E. E. 1939. Some California wildlife-forest relationships. U.S. Dept. Agriculture, Wildlife Research and Management Leaflet BS-132: 5 PP.

KANGUR, R. 1954. Shrews as tree seed eaters in the Douglas fir region. Oregon State Board of Forestry, Research Note 17: 23 pp.

LUNDBERG, G. 1946. Ekorrskador pa granplanteringar. (Squirrel damage to Norway spruce plantations). Skogen 33(13): 204-205.

METZGER, C. 1946. Om ekorren som skadedjur pa tall. (On the squirrel as a pest of pine). Skogen $33(8): 132$.

MOORE, A. W. 1940. Wild animal damage to seed and seedlings on cut-over Douglas fir lands of Oregon and Washington. U.S. Dept. Agriculture, Tech. Bull. 706: 27 pp.

NOVIKOV, G. A. 1953. Rodi pozvonocnyh zivotnyl $\mathrm{v}$ zizni lesa. (Role of vertebrates in the life of the forest). Zivotniij mir S.S.S.R., Esnaä zona. (Animal Life of the U.S.S.R,, Forest zone). Akademiä Nauk, S.S.S.R., (Institute of Zoology, Moscow) 4:599-630.

ROWE, J. S. 1952. Squirrel damage to white spruce. Canada, Department of Resources and Development, Silvicultural Leaflet $61: 2$ pp.

SMITH, C. F. and S. E. ALDOUS, 1947. The influence of mammals and birds in retarding artificial and natural re-seeding of coniferous forests in the U.S. Journal Forestry 45(5): $361-369$.

WILLIS, C. P. 1914. The control of rodents in field seeding. Proceedings Society American Foresters 9: 365-379. 